\title{
ICT integration and teachers' confidence in using ICT for teaching and learning in Queensland state schools
}

\author{
Romina M. Jamieson-Proctor \\ Griffith University \\ Paul C. Burnett \\ Charles Sturt University \\ Glenn Finger and Glenice Watson \\ Griffith University
}

\begin{abstract}
Information and communication technology (ICT) curriculum integration is the apparent goal of an extensive array of educational initiatives in all Australian states and territories. However, ICT curriculum integration is neither value neutral nor universally understood. The literature indicates the complexity of rationales and terminology that underwrite various initiatives; various dimensions and stages of integration; inherent methodological difficulties; obstacles to integration; and significant issues relating to teacher professional development and ICT competencies (Jamieson-Proctor, Watson, \& Finger, 2003). This paper investigates the overarching question: Are ICT integration initiatives making a significant impact on teaching and learning in Queensland state schools? It reports the results from a teacher survey that measures the quantity and quality of student use of ICT. Results from 929 teachers across all year levels and from 38 Queensland state schools indicate that female teachers $(73 \%$ of the full time teachers in Queensland state schools in 2005) are significantly less confident than their male counterparts in using ICT with students for teaching and learning, and there is evidence of significant resistance to using ICT to align curriculum with new times and new technologies. This result supports the hypothesis that current initiatives with ICT are having uneven and less than the desired results system wide. These results require further urgent investigation in order to address the factors that currently constrain the use of ICT for teaching and learning.
\end{abstract}

\section{Introduction}

Rapid technological change and global communication are facts of life in the 21st century. The New London Group (1996) proposed that the closing decades of the 20th century and the beginning of the 21st century were and 
would be characterised by change in almost every aspect of people's working, public and private lives. Consequently, the appearance of information and communication technology (ICT) in schools through improved provision of computer hardware, infrastructure and connectivity should not be seen as an isolated example of change. More correctly, it is evidence of the global, social and technological changes that have contributed to the 'new times' in which we all live. Further, it is imperative that educators are aware of and able to skilfully manage at the classroom level the impacts that result from social, cultural, political, and economic trends and educational policies and programs. Roblyer (2004) states that

One of the things that make teaching so challenging is that it goes on in an environment that mirrors - and sometimes magnifies - some of society's most profound and problematic issues. Adding computers to this mix makes the situation even more complex. Yet to integrate technology successfully into their teaching, educators must recognize and be prepared to work in this environment with all of its subtleties and complexities. (p.15)

In education, such sweeping global, social and technological changes cause unavoidable dissonance as teachers who grew up and were trained in earlier times try to forecast and prepare themselves and others for future times (Luke, 2001). It is likely that this dissonance is compounded by concerns such as those raised by Hodas (1993) who proposed that a conservative conception of what schools should be like can lead to technology refusal, and a resultant resistance by teachers to change familiar practices. Research on teacher integration of computers has generally reported very little impact on classroom teaching and learning. Explanations offered for this include the influence of teacher confidence and expertise, and teacher beliefs about the potential for ICT to make a difference to student learning, as well as issues around teacher professional development, school technological infrastructure and technical support, along with the need for leadership (Cowie \& Jones, 2005). Associated with the plethora of ICT initiatives for students there have been moves to foster teacher use of ICT through such initiatives as providing laptops to teachers and principals (Cunningham, Kerr, McEune, Smith \& Harris, 2003). Research is just beginning to explore the impact of these initiatives on teachers.

In 2003 the British Educational Communications and Technology Agency (BECTA) commissioned two literature reviews and a teacher survey to identify the factors which hinder or promote the effective use of ICT by teachers (BECTA, 2003a, 2003b). The BECTA (2003a) report collates evidence from a range of sources on the actual and perceived barriers to teacher uptake of ICT. It draws on the literature associated with teachers' use of ICT, and also on a small scale teacher survey. It is published in conjunction with a companion report (BECTA, 2003b) looking at the factors 
that enable teachers to make successful use of ICT. Key findings of the BECTA (2003a) report include: (1) Confidence, time and access to quality resources are major factors in determining teachers' engagement with ICT; (2) Recurring technical faults, and the expectation of faults occurring during teaching sessions, are likely to reduce teacher confidence and cause teachers to avoid using the technology in future lessons; (3) Resistance to change is a factor that prevents the full integration of ICT in the classroom. In particular, teachers who do not realise the advantages of using technology in their teaching are less likely to make use of ICT; (4) There are close relationships between many of the identified barriers to ICT use, and any factors influencing one barrier are likely also to influence several other barriers. For example teacher confidence is directly affected by levels of personal access to ICT, levels of technical support and the quality of training available (BECTA, 2003a, p. 3).

The educational challenges associated with these issues require close scrutiny, analysis and responses to capitalise upon the affordances of ICT for improving teaching and learning. Thus, there is an important need to identify the significant research issues with respect to ICT use for teaching and learning.

According to Brady and Kennedy (2003), “Australian governments have clearly taken up the challenge of transforming schools to meet the challenges of the information age" (p. 97). Underlying the plethora of recent ICT initiatives are notions of ICT possibilities and the transformational potential of ICT. For example, in 2002, the Queensland Government outlined its vision to integrate ICT into teaching and learning within Queensland state schools by launching the three-year ICT for Learning Strategy. The then Director General of Education Queensland stated:

ICT are at the core of teaching and learning in the 21st Century.

Queensland's future depends on how successfully we integrate ICT in the curriculum and daily learning and teaching.... Many teachers already use computers to enliven teaching and inspire students. In order to build a 21st Century schooling system..., we need teachers to understand how ICT promote higher order thinking skills and deepen understanding in all key learning areas (State of Queensland, 2002).

The ICT for Learning Strategy played an important role in connecting teachers and students with new technologies, developing a sustainable technology infrastructure in schools and providing more funds for ICT in Queensland schools, including teacher professional development. "As the number of ICT devices such as computers, digital cameras and personal digital assistants increased exponentially in classrooms and teachers underwent professional development, innovation in using new 
technologies to deliver the curriculum became more commonplace throughout the state" (Queensland Government, 2005). The subsequent Smart Classrooms three-year strategy launched in 2005 sets a new direction for ICT in schools. This strategy provides a cohesive, future focused mix of products and services for schools to teach, manage, learn and innovate with new technologies, and specifically focuses on sustainability, utilisation and transformation (Queensland Government, 2005). The strategy intends to provide an expanded package of ICT support and access to schools. In turn, the use of ICT in schools is to be maximised to take best advantage of the department's extensive ICT investment. Further, it is intended that new technologies will provide teachers with opportunities to transform the way they work and develop new approaches to facilitate learning. At the core of the Smart Classrooms strategy is the belief that: "the critical mass of classroom integration reached during the past three years will be the foundation of the next step in the evolution of ICT and learning: making ICT integral to learning" (Queensland Government, 2005).

This ICT innovation trajectory is not unique to Queensland. All States in Australia, and for that matter most countries in the world, have developed similar initiatives, strategies and rhetoric (DfES, 2002; Finger, 2003; Finger \& Trinidad, 2002; Kommers, 2000; MCEETYA, 2002). The overt expectation by governments and communities of schools and teachers is that they will provide students with access to ICT experiences that enrich their learning opportunities. However, an important question that needs to be asked and answered is: Are these statements and initiatives making a significant impact on teaching and learning?

This paper reports the results obtained from an investigation of teacher perceptions about their confidence to use ICT with their students for teaching and learning and its resultant impact on the quantity and quality of student use of ICT for learning in Queensland state schools.

\section{Method}

\section{Subjects}

The subjects involved in this study were 929 teachers from 38 Queensland state schools who voluntarily applied the Learning with ICT: Measuring ICT Use in the Curriculum instrument (Jamieson-Proctor, Watson \& Finger, 2005) to their individual teaching context in late 2003 as part of Education Queensland's (EQ) ICTs for Learning Annual Census. Of the total of 929 teachers, 133 teachers came from seven schools classified by Education Queensland as in the low socio-economic band, 268 came from 13 schools classified as in the mid-low socio-economic band, 372 came from 13 schools 
classified as in the mid-high socio-economic band, and 156 came from five schools, classified as in the high socio-economic band.

Of the total number, $76 \%$ (706) of teachers completing the instrument were female. Table 1 displays demographic information obtained from the data with respect to school type, years of teaching experience and perceived confidence of teachers in using ICT with students for teaching and learning. As can be seen from Table 1,58\% of teachers surveyed had more than 10 years teaching experience and $57 \%$ indicated that they were reasonably confident or very confident users of ICT for teaching and learning.

Table 1: Demographic information detailing teacher numbers by school type, years of teaching experience and confidence in using ICT for teaching and learning

\begin{tabular}{|c|c|c|c|}
\hline & & $\begin{array}{l}\text { Number of } \\
\text { teachers }\end{array}$ & $\%$ \\
\hline \multirow{6}{*}{ School type } & Preschool & 26 & 2.8 \\
\hline & Primary & 513 & 54.9 \\
\hline & Secondary & 360 & 38.5 \\
\hline & School of Distance Ed & 1 & 0.1 \\
\hline & Special Education Unit & 29 & 3.1 \\
\hline & Total & 929 & 100 \\
\hline \multirow{4}{*}{$\begin{array}{l}\text { Years of teaching } \\
\text { experience }\end{array}$} & $0-10$ years & 393 & 42.3 \\
\hline & $11-20$ years & 277 & 29.8 \\
\hline & $21+$ years & 259 & 27.9 \\
\hline & Total & 929 & 100 \\
\hline \multirow{5}{*}{$\begin{array}{l}\text { Confidence to use } \\
\text { ICT for teaching } \\
\text { and learning }\end{array}$} & Very little confidence & 84 & 9.0 \\
\hline & Some confidence & 312 & 33.6 \\
\hline & Reasonably confident & 406 & 43.7 \\
\hline & Very confident & 127 & 13.7 \\
\hline & Total & 929 & 100 \\
\hline
\end{tabular}

Table 2 contains a breakdown of the demographic data pertaining to Year levels and curriculum areas and the teachers' perception of the extent to which their students use ICT at each Year level and in each curriculum area they teach.

\section{Measurement instrument and procedures}

Besides the demographic data on teachers (gender, school type, years of teaching experience, confidence to use ICT with students for teaching and 
learning, year levels and curriculum areas currently taught), the Learning with ICT: Measuring ICT Use in the Curriculum instrument contains 20 items, with response categories on a 4-point Likert scale ranging from Never (1) to Very Often (4), that investigate both the quantity and quality of student use of ICT for learning.

Table 2: Percent of teachers who indicated their students use ICT by year level and curriculum area that they currently teach

\begin{tabular}{|c|c|c|c|c|c|c|}
\hline \multirow{2}{*}{\multicolumn{2}{|c|}{\begin{tabular}{|l|} 
\\
$\begin{array}{l}\text { Students use of ICT by year level and } \\
\text { curriculum area }\end{array}$ \\
\end{tabular}}} & \multicolumn{5}{|c|}{$\begin{array}{l}\% \text { of respondents by year level and } \\
\text { curriculum area taught who indicated } \\
\text { students currently use ICT }\end{array}$} \\
\hline & & \multirow{2}{*}{$\begin{array}{c}\text { Never } \\
28 \\
\end{array}$} & \multirow{2}{*}{$\begin{array}{c}\begin{array}{c}\text { Some- } \\
\text { times }\end{array} \\
39\end{array}$} & \multirow{2}{*}{$\begin{array}{c}\text { Often } \\
20\end{array}$} & \multirow{2}{*}{$\begin{array}{c}\begin{array}{c}\text { Very } \\
\text { often }\end{array} \\
13\end{array}$} & \multirow{2}{*}{\begin{tabular}{|c|}
$\begin{array}{c}\text { Total } \\
\%\end{array}$ \\
100 \\
\end{tabular}} \\
\hline \multirow{15}{*}{$\begin{array}{l}\text { Year } \\
\text { levels }\end{array}$} & Preschool/Prep & & & & & \\
\hline & Year 1 & 17 & 52 & 20 & 11 & 100 \\
\hline & Year 2 & 13 & 48 & 29 & 10 & 100 \\
\hline & Year 3 & 11 & 51 & 32 & 6 & 100 \\
\hline & Year 4 & 13 & 38 & 42 & 7 & 100 \\
\hline & Year 5 & 12 & 28 & 47 & 13 & 100 \\
\hline & Year 6 & 11 & 37 & 34 & 18 & 100 \\
\hline & Year 7 & 10 & 35 & 35 & 20 & 100 \\
\hline & Year 8 & 10 & 62 & 17 & 11 & 100 \\
\hline & Year 9 & 7 & 58 & 25 & 10 & 100 \\
\hline & Year 10 & 7 & 53 & 27 & 13 & 100 \\
\hline & Year 11 & 8 & 44 & 29 & 19 & 100 \\
\hline & Year 12 & 7 & 42 & 30 & 21 & 100 \\
\hline & Specialist Teacher & 24 & 30 & 24 & 22 & 100 \\
\hline & Total \% & 11 & 45 & 30 & 14 & 100 \\
\hline \multirow{12}{*}{$\begin{array}{l}\text { Curricul- } \\
\text { um areas }\end{array}$} & English & 1 & 49 & 42 & 8 & 100 \\
\hline & Mathematics & 10 & 66 & 21 & 3 & 100 \\
\hline & The Arts & 33 & 51 & 13 & 3 & 100 \\
\hline & Studies of Society \& Environment & 10 & 52 & 28 & 10 & 100 \\
\hline & Science & 16 & 56 & 23 & 5 & 100 \\
\hline & Languages Other Than English & 69 & 22 & 7 & 2 & 100 \\
\hline & Technology & 8 & 38 & 35 & 19 & 100 \\
\hline & Health \& Physical Education & 62 & 32 & 4 & 2 & 100 \\
\hline & Preschool Curriculum & 65 & 25 & 8 & 2 & 100 \\
\hline & New Basics Curric. Organisers & 41 & 27 & 21 & 11 & 100 \\
\hline & Vocational Education & 41 & 34 & 15 & 10 & 100 \\
\hline & Total \% & 32 & 41 & 20 & 7 & 100 \\
\hline
\end{tabular}

Two frequency of use scales are used to reflect the 'current' and 'preferred' teacher perceptions of ICT use by their students. The instrument was found to contain two strong factors. The first factor is comprised of 14 items that 
define ICT as a tool for the development of ICT related skills and the enhancement of curriculum learning outcomes. The second factor comprises 6 items that define ICT as an integral component of reforms that change what students learn and how school is structured and organised. Table 3 contains the 20 items with their individual factor loadings and the scale alphas for the Learning with ICT: Measuring ICT Use in the Curriculum instrument (Jamieson-Proctor et al., 2005).

Table 3: Items with Oblimin Rotated Factor Loadings and reliability coefficients for the Learning with ICT: Measuring ICT Use in the Curriculum instrument $(\mathrm{N}=929)$

\begin{tabular}{|c|l|c|c|}
\hline \multicolumn{1}{|c|}{ Factor and Items } & Factor & Factor \\
\hline In my class, students use ICTs to... & 1 & 2 \\
\hline 2 & provide motivation for curriculum tasks. & .786 & \\
\hline 3 & develop functional competencies in a specified curriculum area. & .734 & \\
\hline 4 & actively construct knowledge that integrates curriculum areas. & .814 & \\
\hline 5 & $\begin{array}{l}\text { actively construct their own knowledge in collaboration with } \\
\text { their peers and others. }\end{array}$ & .761 & \\
\hline 6 & synthesise their knowledge. & .823 & \\
\hline 7 & demonstrate what they have learned. & .717 & \\
\hline 9 & $\begin{array}{l}\text { acquire the knowledge, skills, abilities and attitudes to deal with } \\
\text { on-going technological change. }\end{array}$ & .662 & \\
\hline 10 & integrate different media to create appropriate products. & .681 & \\
\hline 12 & $\begin{array}{l}\text { develop deep understanding about a topic of interest relevant to } \\
\text { the curriculum area/s being studied. }\end{array}$ & .801 & \\
\hline 13 & support elements of the learning process. & .742 & \\
\hline 15 & develop a scientific understanding of the world. & .570 & \\
\hline 17 & plan and/or manage curriculum projects. & .739 & \\
\hline 18 & engage in sustained involvement with curriculum activities. & .683 & \\
\hline 20 & undertake formative and/or summative assessment. & .454 & \\
\hline 1 & $\begin{array}{l}\text { engage in independent learning through access to education at a } \\
\text { time, place and pace of their own choosing. }\end{array}$ & & .578 \\
\hline 8 & gain intercultural understanding. & & .747 \\
\hline 11 & $\begin{array}{l}\text { acquire awareness of the global implications of ICT-based } \\
\text { technologies on society. }\end{array}$ & .780 \\
\hline 14 & communicate with others locally and globally. & .538 \\
\hline 16 & understand and participate in the changing knowledge economy. & & .686 \\
\hline 19 & critically evaluate their own and society's values. & .823 \\
\hline & Alpha Reliability Coefficients & 0.94 & 0.86 \\
\hline
\end{tabular}

Education Queensland's ICTs for Learning strategy (Education Queensland, 2004) identified six key ICT drivers which "reflect the necessary conditions for successful learning with ICTs" (Education Queensland, 2004, p. 12): Learning, teaching and the curriculum; Learning and development; ICT infrastructure; Connectivity; ICT support; and Innovation. The ICTs for Learning School Census annually requires all state schools to measure their progress against foundation and preferred futures benchmarks for each of 
the six drivers. Collection of data related to the driver learning, teaching and the curriculum provided challenges for Education Queensland and, prior to 2003, Education Queensland had limited processes for obtaining data related to actual student use of ICT. Data had been collected on the effectiveness of ICT integration through student, staff and parent satisfaction surveys which contained items related to student access to computers, and their confidence in using them. Information pertaining to the use of ICTs in various curriculum areas and year levels was generally supplied by one staff member from each school for the whole school. The reliability of these data was therefore jeopardised due to the collection process. In order to advance the collection of information related to the key ICT driver of learning, teaching and the curriculum, Education Queensland initiated the development and validation of the Learning with ICT: Measuring ICT Use in the Curriculum instrument (Jamieson-Proctor et al., 2005; Proctor, Watson \& Finger, 2003). Education Queensland (EQ) requested individual teachers from all state schools across Queensland to complete the first iteration of this instrument as part of the 2003 ICT School Census in September 2003. These data were then provided to the research team in order to validate the instrument (Jamieson-Proctor et al., 2005; Jamieson-Proctor, Watson, Finger, Grimbeek \& Burnett, in press). This paper reports the results obtained from the administration of the revised scale in late 2003 in Queensland state schools in order to investigate the overarching research question: Are ICT integration initiatives making a significant impact on teaching and learning in Queensland state schools?

\section{Results}

The data were analysed using the Statistical Package for the Social Sciences (SPSS 11.4). Chi-square $\left(\chi^{2}\right)$ tests were used to investigate relationships between teacher gender, years of teaching experience, teacher confidence to use ICT with their students for teaching and learning, school type, curriculum area taught, and Year level taught. Chi-square is a nonparametric test of significance suitable for nominal and ordinal data where the data are classified into discrete categories such as gender or confidence levels and then treated as frequencies. "Chi square tests hypotheses [sic] about the independence (or alternatively the association) of frequency counts in various categories" (Burns, 1990, p. 153). Multivariate analyses of variance (MANOVA) were used to compare the mean scores on both the current and preferred scales of the instrument by gender, years of teaching experience, teacher confidence and school type. This was followed, if the MANOVA was significant $(p<.05)$, by univariate analyses of variance $(F-$ tests) for each of the significant dependent variables. Analyses of variance are appropriately used to test for difference both between and within groups. This section will report the results for each analysis individually. 


\section{Is there a relationship between teacher gender and teachers' confidence to use ICT with their students for teaching and learning?}

When the confidence level of male and female teachers $(1=$ Very Little confidence; 2 = Some confidence; 3 = Reasonably confident; and $4=$ Very confident) was compared using the Pearson chi-square test of significance, a significant difference between genders with respect to their confidence in using ICT with their students for teaching and learning was found, $\chi^{2}(3, N$ $=929)=14.03, p=.00$. Female teachers were more likely to indicate Very little or Some confidence, while male teachers were more likely to indicate that they were Reasonably confident or Very confident. Table 4 displays the frequencies for each category for male and female teachers.

Table 4: Frequency of confidence in using ICT with students for teaching and learning for male and female teachers $(\mathrm{N}=929)$

\begin{tabular}{|l|c|c|c|}
\hline \multirow{2}{*}{} & \multicolumn{2}{|c|}{ Teacher gender } & \multirow{2}{*}{$\%$ of total } \\
\cline { 2 - 3 } & $\%$ Female & $\%$ Male & \\
\hline Very little confidence & 9.6 & 7.2 & 9 \\
\hline Some confidence & 35.8 & 26.5 & 33.6 \\
\hline Reasonably confident & 42.8 & 46.6 & 43.7 \\
\hline Very confident & 11.8 & 19.7 & 13.7 \\
\hline Total \% & 100 & 100 & 100 \\
\hline
\end{tabular}

Further, when the data were recoded to indicate two levels of teacher confidence for ease of comparison (Unconfident $=$ Very little or some confidence, Confident $=$ Reasonably or Very confident) the Pearson chisquare test result indicated that female teachers were less confident than male teachers, $\chi^{2}(1, N=929)=9.71, p=.00$, with $45.5 \%$ of females and $33.6 \%$ of males indicating they were unconfident, while $54.5 \%$ of females and $66.6 \%$ of males indicated they were confident with respect to their use of ICT with their students for teaching and learning. Thus, teacher gender is significantly related to confidence in using ICT with students for this group of teachers.

\section{Is there a difference between male and female teachers with respect to the frequency that their students use ICT for learning?}

A MANOVA was used to compare the current and preferred means of male and female teachers for the two dimensions of ICT use defined by the instrument, namely (D1) ICT as a tool for the development of ICT related skills and the enhancement of curriculum learning outcomes, and (D2) ICT as an integral component of reforms that change what students learn and how school is structured and organised. 
The multivariate result was significant for gender, Pillai's Trace $=.02, F=$ $3.50, d f=(4,924), p=.01$, indicating a difference in the level of student use of ICT between male and female teachers. The univariate $F$ tests showed there was a significant difference between males and females for D1, $F=$ $7.73, d f=(1,927), p=.01$, and D2, $F=6.59, d f=(1,927), p=.01$, with respect to how frequently their students currently use ICT.

However, the $F$ tests for both dimensions on the preferred scale were not significant, $F=1.55, d f=(1,927), p=.21$ for $\mathrm{D} 1$, and $F=.00, d f=(1,927), p=$ .99 for D2. Thus, male and female teachers were not significantly different in their preferred level of student use of ICT. Table 5 displays the means for male and female teachers for the current and preferred scales for both dimensions of student ICT use.

Table 5: A comparison of means (with Standard Deviations) for male and female teachers for the two dimensions of ICT use by students for both the Current and Preferred scales $(\mathrm{N}=929)$

\begin{tabular}{|l|c|c|c|c|}
\hline $\begin{array}{c}\text { Teacher } \\
\text { gender }\end{array}$ & $\begin{array}{c}\text { Dimension 1 } \\
\text { Current Use }\end{array}$ & $\begin{array}{c}\text { Dimension 1 } \\
\text { Preferred Use }\end{array}$ & $\begin{array}{c}\text { Dimension 2 } \\
\text { Current Use }\end{array}$ & $\begin{array}{c}\text { Dimension 2 } \\
\text { Preferred Use }\end{array}$ \\
\hline Female & $1.97(0.61)^{*}$ & $2.75(0.62)$ & $1.58(0.54)^{*}$ & $2.47(0.70)$ \\
\hline Male & $2.1(0.60)^{*}$ & $2.81(0.59)$ & $1.68(0.56)^{*}$ & $2.47(0.67)$ \\
\hline
\end{tabular}

* indicates significance at $p<.05$

As can be seen in Table 5, male teachers perceived that their students currently use ICT more frequently than the students of female teachers for both the curriculum enhancement and transformation dimensions of ICT use. However, a non-significant result for both dimensions of the preferred scale indicates that there is no real difference between male and female teachers with respect to how they would prefer their students to use ICT.

\section{Is there a difference between unconfident and confident teachers in the frequency that their students use ICT for learning?}

A MANOVA was used to compare the current and preferred means on both dimensions of ICT use of teachers with little confidence as opposed to teachers who indicated they were confident in using ICT with their students for teaching and learning.

The multivariate result was significant for teacher confidence, Pillai's Trace $=.10, F=26.75, d f=(4,924), p=.00$, indicating a difference in the level of student use of ICT between confident and unconfident teachers. The univariate $F$ tests showed there was a significant difference between confident and unconfident teachers for D1, $F=104.10, d f=(1,927), p=.00$, and D2, $F=63.66, d f=(1,927), p=.00$, with respect to how frequently their students currently use ICT. There was also a significant difference between 
confident and unconfident teachers for D1, $F=55.44, d f=(1,927), p=.00$, and D2, $F=27.06, d f=(1,927), p=.00$, with respect to how frequently they preferred their students to use ICT. Table 6 displays the means for confident and unconfident teachers for the current and preferred scales for both dimensions of student ICT use.

Table 6: A comparison of means (with Standard Deviations) for confident and unconfident teachers for the two dimensions of student ICT use for both the Current and Preferred scales $(\mathrm{N}=929)$

\begin{tabular}{|l|c|c|c|c|}
\hline $\begin{array}{c}\text { Teacher } \\
\text { confidence level }\end{array}$ & $\begin{array}{c}\text { Dimension 1 } \\
\text { Current Use }\end{array}$ & $\begin{array}{c}\text { Dimension 1 } \\
\text { Preferred Use }\end{array}$ & $\begin{array}{c}\text { Dimension 2 } \\
\text { Current Use }\end{array}$ & $\begin{array}{c}\text { Dimension 2 } \\
\text { Preferred Use }\end{array}$ \\
\hline Unconfident & $1.77(0.51)^{*}$ & $2.59(0.60)^{*}$ & $1.44(0.47)^{*}$ & $2.33(0.70)^{*}$ \\
\hline Confident & $2.17(0.63)^{*}$ & $2.89(0.59)^{*}$ & $1.72(0.58)^{*}$ & $2.57(0.67)^{*}$ \\
\hline
\end{tabular}

* indicates significance at $p<.05$

Thus, teachers who feel more confident in using ICT with their students for teaching and learning indicated that their students currently use ICT more frequently on both dimensions of use. Further, they indicated that they would prefer their students to use ICT more than would less confident teachers.

\section{Is there a relationship between length of teaching experience and confidence to use ICT with students for teaching and learning?}

When the teachers' confidence to use ICT with their students for teaching and learning was compared based on their different numbers of years of teaching experience (0-10 years; $11-20$ years; $>20$ years) a non-significant difference was found, $\chi^{2}(2)=3.81, p=.15$. Table 7 shows the frequency of responses provided by each of the three experience groups.

Table 7: Frequency of confidence in using ICT with students for teaching and learning for teachers with different numbers of years of experience $(\mathrm{N}=929)$

\begin{tabular}{|c|c|c|c|}
\hline & \multicolumn{2}{|c|}{ Teacher confidence level } & \multirow{2}{*}{$\%$ of total } \\
\hline & $\%$ Unconfident & $\%$ Confident & \\
\hline 0-10 years experience & 38.6 & 45 & 42.3 \\
\hline 11-20 years experience & 31.8 & 28.3 & 29.8 \\
\hline $21+$ years experience & 29.5 & 26.6 & 27.9 \\
\hline Total \% & 100 & 100 & 100 \\
\hline
\end{tabular}

* significant at $p<.05$

Thus, years of teaching experience (and probably therefore teacher age) is not significantly related to teacher confidence in using ICT with students for teaching and learning for this group of teachers. 


\section{Is the frequency that students use ICT for learning affected by the number of years of teaching experience of the teacher?}

A MANOVA was used to compare the current and preferred means of each dimension of ICT use by the teachers' years of experience $(0-10 \mathrm{yrs}$, 11-20 yrs, 21+ yrs).

The multivariate result was significant for years of teaching experience by frequency of student use of ICT, Pillai's Trace $=.03, F=3.77, d f=(8,1848), p$ $=.00$, indicating a multivariate effect. The univariate $F$ tests showed there was no significant difference between teachers with different numbers of years of experience for the current scale. However, years of experience did impact significantly on the teachers' preferred student frequency of use for the first dimension, $F=3.61, d f=(2,926), p=.03$, as well as the second dimension, $F=7.34, d f=(2,926), p=.00$.

Independent samples $t$ tests were then conducted to compare the means between the three experience groups namely, 0-10 yrs and 11-20 yrs, 0-10 yrs and 21+ yrs, and 11-20 yrs and 21+ yrs, for both dimensions of use for the preferred scale. The results indicated teachers with 0-10 yrs teaching experience preferred their students to use ICT more than teachers with 1120 yrs experience, $t(668)=3.22, p=.00(\mathrm{DE})$, and more than teachers with $21+$ yrs experience, $t(668)=3.22, p=.00(\mathrm{DF})$ for the second dimension of ICT use. Also, teachers with $0-10$ yrs experience preferred their students to use ICT more than teachers with $21+$ yrs experience, $t(650)=2.49, p=.01$ $(\mathrm{AB})$ for the first dimension of ICT use. Table 8 summarises these results and indicates the significant $t$ test differences between the three groups.

These results indicate that the teachers' years of experience has no significant impact on the current frequency of student use of ICT, but teachers with less years of experience would seem to prefer their students use ICT more frequently to both enhance and transform the curriculum.

\section{Is there a relationship between school type and teacher confidence to use ICT with their students for teaching and learning?}

As there was data from only one Distance Education teacher (see Table 1), his/her data was recoded as system missing for this analysis to improve the reliability of the test. The confidence levels of teachers from four different school types (Preschool, Primary, Secondary and Special Education) were compared using the Pearson chi-square test of significance and the result was significant, $\chi^{2}(9)=20.53, p=.02$, indicating that levels of teacher confidence to use ICT with their students for teaching and learning is related to the type of school they teach at. Independent samples $t$ tests 
Table 8: A comparison of means for the two dimensions of ICT use for both the Current and Preferred scales based on the teachers' years of experience $(\mathrm{N}=929)$

\begin{tabular}{|c|c|c|c|c|}
\hline $\begin{array}{c}\text { Dimension } \\
\text { and scale }\end{array}$ & $\begin{array}{c}\text { Years of teacher } \\
\text { experience }\end{array}$ & $\mathrm{n}$ & Mean & Std. dev. \\
\hline \multirow{4}{*}{ D1 current } & $0-10$ & 393 & 2.01 & .61 \\
\cline { 2 - 5 } & $11-20$ & 277 & 1.97 & .61 \\
\hline \multirow{4}{*}{ D1 preferred } & $21+$ & 259 & 2.01 & .61 \\
\cline { 2 - 5 } & $0-10$ & 393 & $2.82 \mathrm{~A}$ & .61 \\
\cline { 2 - 5 } & $11-20$ & 277 & 2.73 & .60 \\
\hline \multirow{3}{*}{ D2 current } & $21+$ & 259 & $2.70 \mathbf{B}$ & .63 \\
\cline { 2 - 5 } & $0-10$ & 393 & 1.60 & .55 \\
\cline { 2 - 5 } & $11-20$ & 277 & 1.56 & .55 \\
\hline \multirow{2}{*}{ D2 preferred } & $21+$ & 259 & 1.64 & .55 \\
\cline { 2 - 5 } & $0-10$ & 393 & $2.57 \mathbf{D}$ & .68 \\
\cline { 2 - 5 } & $11-20$ & 277 & $2.40 \mathbf{E}$ & .71 \\
\hline
\end{tabular}

$\mathrm{AB}, \mathrm{DE}, \mathrm{DF}$ significant at $p<.05$

were then computed to compare the means between school type pairs namely, Preschool/Primary, Preschool/Secondary, Preschool/Special Education, Primary/Secondary, Primary/Special Education, and Secondary/Special Education. The results were significant only for the comparison of Secondary and Special Education teachers' means, $t(387)=$ $2.20, p=.03$, indicating that Secondary teachers were more confident in using ICT with their students for teaching and learning than were Special Education teachers. These results are summarised in Table 9.

Table 9: Confidence levels of teachers from different school types to use ICT with their students for teaching and learning $(\mathrm{N}=928)$

\begin{tabular}{|l|c|c|c|}
\hline \multicolumn{1}{|c|}{ School type } & $\mathrm{n}$ & Mean & Std. dev. \\
\hline Preschool & 26 & 2.50 & .65 \\
\hline Primary & 513 & 2.60 & .81 \\
\hline Secondary & 360 & $2.68^{*}$ & .88 \\
\hline Special Education & 29 & $2.31^{*}$ & .66 \\
\hline
\end{tabular}

\section{Is the frequency that students use ICT for learning affected by the type of school?}

A MANOVA was used to compare the current and preferred means of each dimension of ICT use by the teachers' school type (Preschool, Primary, Secondary and Special Education).

The multivariate result was significant for school type by frequency of student use of ICT, Pillai's Trace $=.03, F=2.39, d f=(12,2769), p=.00$, indicating a multivariate effect. The univariate $F$ tests showed there was a 
significant difference between teachers from different school types for D1 current scale, $F=4.88, d f=(3,924), p=.00$, D1 preferred scale, $F=6.86, d f=$ $(3,924), p=.00, \mathrm{D} 2$ current scale, $F=4.53, d f=(3,924), p=.00$, and D2 preferred scale, $F=6.26, d f=(3,924), p=.00$.

Independent samples $t$ tests were then conducted to compare the means between pairs of school types for both dimensions of use for both scales. The results indicated that primary students currently use ICT more than preschool students for dimension $1, t(537)=-3.26, p=.00(\mathrm{AB})$, and dimension $2, t(537)=-3.43, p=.00$ (IJ). Also, primary teachers prefer their students to use ICT more than preschool teachers for dimension $1, t(537)=$ $-4.3, p=.00(\mathrm{EF})$, and dimension $2, t(537)=-4.29, p=.00(\mathrm{MN})$. Secondary students currently use ICT more than preschool students for dimension $1, t$ $(384)=-3.34, p=.00(\mathrm{AC})$, and dimension $2, t(384)=-3.54, p=.00(\mathrm{IK})$ and secondary teachers prefer their students to use ICT more than preschool teachers for dimension $1, t(384)=-4.3, p=.00(\mathrm{EG})$, and dimension $2, t$ $(384)=-4.29, p=.00(\mathrm{MO})$. Finally, special education students currently use ICT more than preschool students for dimension $2, t(53)=-2.26, p=.03$ (IL) and special education teachers prefer their students to use ICT more than preschool teachers for dimension 1, $t(53)=-2.17, p=.03(\mathrm{EH})$ and dimension $2, t(53)=-3.27, p=.00(\mathrm{MP})$.

Table 10: A comparison of means for the two dimensions of ICT use for both the Current and Preferred scales based on school type $(\mathrm{N}=929)$

\begin{tabular}{|l|l|c|cc|c|}
\hline $\begin{array}{c}\text { Dimension } \\
\text { and scale }\end{array}$ & \multicolumn{1}{|c|}{ School type } & $\mathrm{n}$ & \multicolumn{2}{|c|}{ Mean } & Std. dev. \\
\hline D1 current & Preschool & 26 & 1.61 & $\mathrm{~A}$ & .47 \\
& Primary & 513 & 2.01 & $\mathrm{~B}$ & .61 \\
& Secondary & 360 & 2.02 & $\mathrm{C}$ & .62 \\
& Special Education & 29 & 1.80 & $\mathrm{D}$ & .45 \\
\hline D1 preferred & Preschool & 26 & 2.25 & $\mathrm{E}$ & .72 \\
& Primary & 513 & 2.78 & $\mathrm{~F}$ & .61 \\
& Secondary & 360 & 2.78 & $\mathrm{G}$ & .60 \\
& Special Education & 29 & 2.64 & $\mathrm{H}$ & .59 \\
\hline D2 current & Preschool & 26 & 1.23 & $\mathrm{I}$ & .44 \\
& Primary & 513 & 1.61 & $\mathrm{~J}$ & .55 \\
& Secondary & 360 & 1.63 & $\mathrm{~K}$ & .56 \\
& Special Education & 29 & 1.89 & $\mathrm{~L}$ & .61 \\
\hline D2 preferred & Preschool & 26 & 1.90 & $\mathrm{M}$ & .61 \\
& Primary & 513 & 2.49 & $\mathrm{~N}$ & .70 \\
& Secondary & 360 & 2.48 & $\mathrm{O}$ & .68 \\
& Special Education & 29 & 2.49 & $\mathrm{P}$ & .73 \\
\hline
\end{tabular}

AB, AC, EF, EG, EH, IJ, IK, IL, MN, MO, MP significant at $p<.05$

Table 10 summarises these results and indicates the significant $t$ test differences between the four teacher groups. 


\section{Is there a relationship between the teachers' curriculum area and their confidence to use ICT with their students for teaching and learning?}

Teachers were asked to indicate the extent to which they believed their students used ICT in the curriculum areas they taught. In the event that they taught more than one curriculum area (e.g. secondary teachers), they were advised to focus on one class only, preferably the class they taught for the most time. However, there is still a possibility that individual teachers selected more than one curriculum area. Eleven curriculum areas or curriculum clusters were provided from which teachers could choose English, Mathematics, the Arts, Study of Society and Environment (SOSE), Science, Languages Other Than English (LOTE), Technology, Health and Physical Education (HPE), Preschool curriculum, New Basics curriculum clusters, and Vocational Education.

Results from the Pearson chi-square tests of significance indicate that curriculum area was significantly related to the teachers' confidence levels in using ICT with their students for teaching and learning in all but three curriculum areas (LOTE, HPE and New Basics). Table 11 summarises these results.

Table 11: Summary of results for the impact of curriculum area on teachers' confidence to use ICT with their students for teaching and learning $(\mathrm{N}=929)$

\begin{tabular}{|l|c|c|c|c|}
\hline \multicolumn{1}{|c|}{ Curriculum area } & $\mathrm{n}$ & $\begin{array}{c}\text { Pearson } \\
\text { chi-square value }\end{array}$ & $\mathrm{df}$ & $p<.05$ \\
\hline English & 632 & $45.29^{*}$ & 3 & .00 \\
\hline Mathematics & 580 & $24.05^{*}$ & 3 & .00 \\
\hline The Arts & 461 & $19.75^{*}$ & 3 & .00 \\
\hline SOSE & 544 & $39.26^{*}$ & 3 & .00 \\
\hline Science & 501 & $26.11^{*}$ & 3 & .00 \\
\hline LOTE & 325 & 6.72 & 3 & .08 \\
\hline Technology & 519 & $36.54^{*}$ & 3 & .00 \\
\hline HPE & 392 & 3.11 & 3 & .38 \\
\hline Preschool Curriculum & 194 & $7.90^{*}$ & 3 & .04 \\
\hline New Basics & 146 & 7.56 & 3 & .06 \\
\hline Voc. Ed. & 174 & $18.04^{*}$ & 3 & .00 \\
\hline
\end{tabular}

Further, the means appear to indicate that when teachers reported that they were confident in using ICT with their students for teaching and learning in English, Mathematics, the Arts, SOSE, Science, Technology, Preschool curriculum and Vocational Education, then they also appeared to indicate consistently that their students used ICT often or very often. Conversely, 
when they indicated that they were unconfident in using ICT with their students, then they reported that their students used ICT less frequently.

\section{Is there a difference between mean scores for the current and preferred scales for each of the two dimensions of student use of ICT?}

Paired samples $t$ tests were used to compare mean pairs for dimension 1 and dimension 2, for the current and preferred scales. Significant differences resulted for the comparison between the current $(M=2.00, S D$ $=0.61)$ and preferred scales $(M=2.76, S D=0.61)$ for dimension $1, t(928)=-$ $46.73, p=.00$; current $(M=1.60, S D=0.55)$ and preferred scales $(M=2.47$, $S D=0.70)$ for dimension $2, t(928)=-47.71, p=.00$; dimension $1(M=2.00$, $S D=0.61)$ and dimension $2(M=1.60, S D=0.55)$ for the current scale, $t(928)=29.26, p=.00$; and dimension $1(M=2.76, S D=0.61)$ and dimension $2(M=2.47, S D=0.70)$ for the preferred scale, $t(928)=20.11, p=.00$.

Table 12 contains the means and standard deviations for each of the two dimensions on each of the two scales and also indicates the significant mean differences.

Table 12: A comparison of means for each of the dimensions of ICT use for the Current and Preferred scales $(\mathrm{N}=929)$

\begin{tabular}{|l|c|c|c|}
\hline Dimension and scale & $\mathrm{n}$ & Mean & SD \\
\hline D1 Current & 929 & $2.00 \mathrm{~A}$ & 0.61 \\
\hline D1 Preferred & 929 & $2.76 \mathrm{~B}$ & 0.61 \\
\hline D2 Current & 929 & $1.60 \mathrm{C}$ & 0.55 \\
\hline D2 Preferred & 929 & $2.47 \mathrm{D}$ & 0.70 \\
\hline * Significant paired & & A,B & \\
differences $(p<.05)$ & & A, C & \\
& & B,D & \\
& & C,D & \\
\hline
\end{tabular}

These results indicate that teachers would prefer their students to use ICT more frequently than they currently are for both enhancing and transforming curriculum experiences $(\mathrm{AB}, \mathrm{CD})$. Teachers also indicated that they currently use ICT more frequently to enhance the current curriculum than to transform it $(\mathrm{AC})$ and they prefer this trend to continue (BD).

\section{Conclusion}

This paper has investigated nine sub-questions related to the overarching research question: Are ICT integration initiatives making a significant impact on teaching and learning in Queensland state schools? The paper 
has provided data on teachers' confidence to use ICT with students for teaching and learning, related to their gender, years of experience, school type and curriculum area taught. It has also provided evidence of the quantity and quality of student use of ICT for learning related to teacher gender, confidence, years of experience and school type. The analysis found that male teachers report significantly higher levels of confidence in using ICT with students for teaching and learning and the students of male teachers or confident teachers use ICT more frequently to both enhance and transform the curriculum. Further, there was no significant relationship between years of teaching experience and teacher confidence, but experience did impact on the level of ICT use that teachers prefer their students to demonstrate, with teachers who have had least experience preferring their students to use ICT more to both enhance and transform the curriculum.

Also, the results indicated that Secondary teachers were more confident than Special Education teachers, and that Primary, Secondary and Special Education teachers' students currently use ICT for learning more than students of Preschool teachers. Further, Primary, Secondary and Special Education teachers prefer their students to use ICT more than Preschool teachers to both enhance and transform the curriculum. Teacher confidence was related to student frequency of ICT use in all curriculum areas except LOTE, HPE and New Basics. Differences were also found between 45 of the 55 curriculum pairs with respect to the frequency that students use ICT for learning. On a 4-point scale, Vocational Education, the Arts, Preschool, HPE and LOTE had mean student use of less than 2, with New Basics teachers indicating a very broad distribution of scores $(\mathrm{M}=2.02, \mathrm{SD}=1.03)$. Finally, when the differences between current and preferred levels of student use of ICT for both dimensions were investigated, teachers indicated that they would prefer their students to use ICT more than they are currently using it, to both enhance and transform the curriculum, but they currently use ICT more to enhance the curriculum than to transform it and they prefer this trend to continue.

The results of this investigation involving 929 Queensland teachers strongly support the BECTA (2003a) finding that teacher confidence is a major factor determining teachers' and students' engagement with ICT. Further, teacher resistance to change and to transforming the curriculum with ICT is evident in Queensland, especially among older teachers. The average age of teachers in Queensland state schools in 2005 was 41.8 years. There also appears to be a close relationship between such factors as teacher gender, confidence, school type and curriculum area and these factors impact on the level of student use of ICT. These results provide significant challenges for an education system. The dissonance noted by Luke (2001) is reflected in these results by the fact that teachers prefer to 
enhance the current curriculum rather than transform the curriculum with ICT and move beyond familiar practices to prepare themselves and others for future times. As forecast by Hodas (1993), these results reflect a conservative conception by teachers of what schools should be like and this predisposition may lead to technology refusal, and a resultant resistance by teachers to change familiar practices to align their curriculum with new times and new technologies, regardless of the current system initiatives and imperatives with respect to ICT.

The researchers believe that the evidence supplied by this research should underwrite a full scale investigation by school authorities of, among other things, the factors that afford and constrain teacher confidence in using ICT with students for teaching and learning, and in particular why female teachers, who in 2004 made up 70\% of the full time teachers in Queensland state schools (ABS, 2005) are less confident than their male counterparts. If these results are representative of the state education system in Queensland, then $70 \%$ of students are currently being taught by teachers who are less confident to use ICT than the other 30\%, and 70\% of students use ICT less than the other $30 \%$ as a result of their teacher's lack of confidence. ICT curriculum integration initiatives will have little impact on teaching and learning in Queensland state schools, or elsewhere, unless these issues are addressed and resolved.

\section{References}

Australian Bureau of Statistics (ABS). (2005). Table 65: Full-time equivalent of teaching staff by category of school. [viewed 20 Dec 2005] http: / / www.abs.gov.au /

Brady, L., \& Kennedy, K. (2003). Curriculum construction (2nd ed.). Frenchs Forest, NSW: Pearson Prentice Hall.

British Educational Communications and Technology Agency (BECTA) (2003a). A review of the research literature on barriers to the uptake of ICT by teachers. [viewed 18 Jan 2003 at http:/ / www.BECTA.org.uk/research/index.cfm, verified 19 Oct 2006 at http:/ / partners.becta.org.uk/page_documents/research/barriers.pdf]

British Educational Communications and Technology Agency (BECTA). (2003b). Enabling teachers to make successful use of ICT. [viewed 18 Jan 2003 at http: / / www.BECTA.org.uk/ research/index.cfm, verified 19 Oct 2006 at http:/ / partners.becta.org.uk/page_documents/research/enablers.pdf]

Burns, R. (1990). Introduction to research methods in education. Sydney: Longman Cheshire.

Cowie, B. \& Jones, A. (2005). Digital Horizons: Laptops for teachers evaluation study. [viewed 20 Dec 2005, verified 19 Oct 2006] http: / / www.minedu.govt.nz / web/ downloadable/d d18568_v1/laptop-leaders-report-12-9-with-edits-ds.doc 
Cunningham, M., Kerr, K., McEune, R., Smith, P., \& Harris, S. (2003). Laptops for teachers: An evaluation of the first year of the initiative. (No. 19): BECTA/DfES. [verified 19 Oct 2006] http:/ / partners.becta.org.uk/page_documents/ research/lft_evaluation.pdf

Department for Education and Skills (DfES) (2002). Transforming the way we learn: A vision for the future of ICT in schools. [viewed 4 Nov 2003; not found 19 Oct 2006] http://www.dfes.gov.uk/

Education Queensland (2004). Information and communication technologies for learning. School information kit 2004-2005. [viewed 18 May 2005, not found 19 Oct 2006]

Finger, G. (2003). Information and communications technologies (ICTs) in education: The emergence of digital content initiatives, and systemic ICT initiatives in Australia. Paper presented at the ICASE 2003 World Conference on Science and Technology Education Proceedings (p. 549), 7-10 April. Penang, Malaysia.

Finger, G. \& Trinidad, S. (2002). ICTs for learning: An overview of systemic initiatives in the Australian States and Territories. Australian Educational Computing, 17(2), 3-14. http: / / www.acce.edu.au/journal/journals/vol17_2.pdf

Hodas, S. (1993). Technology refusal and the organisational culture of schools. Education Policy Analysis Archives, 1(10).

Jamieson-Proctor, R., Watson, G. \& Finger, G. (2003). Information and communication technologies (ICTs) curriculum integration performance measurement. Report on the development of an ICT curriculum integration performance measurement instrument. Brisbane, Australia: Griffith University.

Jamieson-Proctor, R., Watson, G., \& Finger, G. (2005). An external evaluation of Education Queensland's ICT Curriculum Integration Performance Measurement Instrument. Brisbane, Qld: Griffith University.

Jamieson-Proctor, R., Watson, G., Finger, G., Grimbeek, P. \& Burnett, P. C. (in press). Measuring the use of Information and Communication Technologies (ICTs) in the classroom. Computers in the Schools.

Kommers, P. (2000). Information and communication technology for education: Research and development for the educational integration of technology in Eastern European countries. Educational Technology Research and Development, 48(3), 104-111.

Luke, A. (2001). Introduction to whole-school literacy planning. How to make literacy policy differentially: Generational change, professionalisation, and literate futures. Paper presented at the ALEA-AATE Conference, Hobart, Tasmania. 
Ministerial Council on Education Employment Training and Youth Affairs (MCEETYA) (2002). Report of the ICT in schools taskforce to MCEETYA 2002. [viewed 31 May 2003 at http:/ / www.edna.edu.au/sibling/mceetya/documents / taskforcereport.pdf, verified 20 Oct 2006 at http:/ /icttaskforce.edna.edu.au/icttaskforce/ webdav/site/icttaskforcesite/users/root/public/taskforcereport.pdf]

Ministerial Council on Education Employment Training and Youth Affairs (MCEETYA) (2003). Learning in and Online world: Research strategy. [viewed $31 \mathrm{Jul}$ 2005 at http:/ / www.mceetya.edu.au/public/public.htm, verified 20 Oct 2006 at http:/ / icttaskforce.edna.edu.au/icttaskforce/webdav/site/icttaskforcesite/ users/root/public/research_strategy.pdf]

New London Group. (1996). A pedagogy of multiliteracies: Designing social futures. Harvard Education Review, 66(1), 60-92.

Proctor, R., Watson, G. \& Finger, G. (2003). Measuring information and communication technology (ICT) curriculum integration. Computers in the Schools, 20(4), 67-87.

Queensland Government (2005). Smart classrooms: A strategy for 2005-2007. Brisbane: Department of Education and the Arts. [verified 20 oct 2006] http: / / education.qld.gov.au/smartclassrooms /

Roblyer, M. (2004). 2004 Update integrating/educational technology into teaching (3rd ed.). Upper Saddle River, NJ: Pearson Merrill Prentice Hall.

State of Queensland (2002). Information and communication technologies for learning: School kit (2002-2003). [viewed 1 Oct 2003, verified 20 Oct 2006] http: / / education.qld.gov.au/itt/learning/docs/infokit.pdf

Taylor, R. (1980). The computer in the school: Tutor, tool, tutee. New York: Teachers College Press.

Dr Romina M. Jamieson-Proctor, Centre for Learning Research, Griffith University

Paul C. Burnett, Centre for Research and Graduate Training, Charles Sturt University

Glenn Finger, Centre for Learning Research, Griffith University

Glenice Watson, Centre for Applied Language, Literacy \& Communication Studies, Griffith University

Address for Correspondence: Dr R. Jamieson-Proctor, School of Education and Professional Studies, Griffith University, Parklands Drive, Gold Coast, Qld 4215, Australia. Email: r.proctor@griffith.edu.au 